\title{
IDENTIFIKASI PENYAKIT LAYU PADA BIBIT GMELINA (Gmelina arborea Roxb.) DI PERSEMAIAN DAN UJI ANTAGONISME Trichoderma sp. SECARA IN VITRO
}

\author{
Yeni Nuraeni*, Illa Anggraeni, Melina Dwi Rosalinda \\ Pusat Penelitian dan Pengembangan Hutan \\ Kampus Balitbang Kehutanan, Jl. Gunung Batu No. 5, Bogor 16610 \\ *email: y.nuraeni999@gmail.com
}

\begin{abstract}
Identification of Wilt Disease on Gmelina Seedlings and In- Vitro Antagonist Test of Trichoderma sp.
\end{abstract}

\begin{abstract}
Gmelina seedlings which were 1.5 months age in the nursery Center for Reseacrh and Development Forests Bogor were attacked by wilt disease over $4.27 \%$. The purpose of study were to determine the patoghens that cause the wilt disease in the nursery and to study the antagonist Trichoderma sp. against the pathogen causing wilt by in vitro as control efforts. The identification result of disease causing wilt on the gmelina seedlings was pathogenic fungus namely Fusariumi sp. The percentage of antagonist test on Trichoderma harzianum (THA) and Trichoderma Cipanas (TC) inhibiting against Fusarium sp. were $40.31 \%$ and $33.55 \%$, respectively.
\end{abstract}

Keywords: Antagonistic, gmelina seedlings, Fusarium sp., wilt disease

\begin{abstract}
ABSTRAK
Bibit gmelina umur 1,5 bulan di persemaian Pusat Penelitian dan Pengembangan Hutan Bogor mengalami serangan penyakit layu dengan persentase serangan sebesar 4,27\%. Penelitian dilakukan untuk mengetahui patogen yang menyebabkan penyakit layu tersebut di persemaian, dan melakukan uji antagonis Trichoderma sp. dengan patogen penyebab layu secara in vitro sebagai upaya pengendaliannya. Hasil identifikasi penyebab penyakit layu pada bibit gmelina adalah cendawan patogen yaitu Fusarium sp. Sedangkan hasil uji antagonisme Trichoderma sp. berturutturut Trichoderma harzianum (THA) dan Trichoderma Cipanas (TC) memiliki daya hambat terhadap Fusarium sp. sebesar $40,31 \%$ dan $33,55 \%$.
\end{abstract}

Kata kunci: Antagonis, bibit gmelina, Fusarium sp., penyakit layu

\section{PENDAHULUAN}

Di Indonesia, Gmelina arborea Roxb. (Verbenaceae) dikenal dengan nama gmelina atau jati putih, dan diluar Indonesia dikenal dengan sebutan melina dan yemane (Streets, 1980). Gmelina merupakan salah satu jenis tanaman berdaun lebar yang tergolong tanaman cepat tumbuh (fast growing species) dengan daur tebang 7 tahun. Tinggi pohon gmelina dapat mencapai 30 meter dengan batang bebas cabang mencapai 15 meter. Gmelina mudah di tanam pada berbagai ketinggian serta berbagai jenis tanah. Syarat tumbuh gmelina dapat dibudayakan pada ketinggian $600 \mathrm{~m}$ dpl dengan curah hujan $800-4.500$ m/tahun (Mulyana \& Asmarahman, 2010). Secara alami, gmelina tumbuh di daerah tropis yang tersebar dari Asia Selatan hingga Asia Tenggara (India, Nepal, Pakistan, Burma, Thailand, Laos, Kamboja dan Vietnam) dan telah ditanam di negara yang beriklim tropis seperti Indonesia, Malaysia dan Pilipina. Kayu gmelina dapat dimanfaatkan sebagai bahan baku industri kayu, seperti papan partikel, inti kayu lapis, korek api, peti kemas, kerajinan serta industri pulp dan kertas (Kosasih \& Danu, 2013).

Untuk memenuhi kebutuhan kayu, pemerintah menggalakkan produksi kayu yang dihasilkan oleh hutan rakyat (Mulyana \& Asmarahman, 2010). Hutan rakyat 
merupakan salah satu sasaran dari program revitalisasi kehutanan untuk memenuhi kebutuhan kayu selain dari hutan alam dan hutan tanaman industri. Defisit kebutuhan kayu yang terus terjadi merupakan salah satu peluang untuk mengembangkan dan membangun hutan rakyat. Jenis tanaman hutan rakyat yang sekarang ini sedang diminati masyarakat antara lain sengon, jabon, gmelina, mahoni, jati, suren, meranti dan kayu afrika. Gmelina merupakan tanaman penghasil kayu yang produktif dan memiliki nilai ekonomi tinggi (Mulyana \& Asmarahman, 2010) dan banyak disukai oleh petani karena cepat tumbuh dan mudah dibudidayakan (Anggraeni \& Mindawati, 2011). Untuk menunjang penanaman dalam pengembangan gmelina, Pusat Litbang Hutan Bogor pada tahun 2015 membuat persemaian gmelina. Pada saat bibit umur 1,5 bulan bibit gmelina menunjukkan gejala layu dan mati. Hasil pengamatan menunjukkan bahwa kematian bibit tersebut disebabkan oleh cendawan patogen. Hal ini dicirikan dengan tidak adanya bau walaupun akar bibit membusuk, sedangkan apabila bibit terserang bakteri akan menimbulkan bau. Untuk menentukan teknik pengendalian yang didalamnya termasuk pencegahan dan pemberantasan, diperlukan penelitian dasar yaitu mengetahui jenis cendawan patogen. Oleh karena itu, tujuan penelitian ini adalah untuk mengetahui jenis cendawan patogen yang menyebabkan penyakit layu pada bibit gmelina di persemaian Pusat Litbang Hutan Bogor dan uji antagonisme cendawan Trichoderma sp. secara in-vitro sebagai dasar pengendalian penyakit di persemaian/lapangan. Trichoderma sp. merupakan agen hayati yang potensial karena memiliki peran sebagai mikoparasit yang agresif yang mampu menyerang patogen tanaman (Tasik \& Widyastuti, 2015).

\section{BAHAN DAN METODE}

\section{Bahan dan Alat}

Bahan- bahan yang digunakan yaitu bibit gmelina umur 1,5 bulan, media agarkentang/PDA $=$ Potatoes Agar Dextrose
(Difco ${ }^{\mathrm{TM}}$ ), akuades, alkohol 70\%, desinfektan berbahan aktif $\mathrm{NaClO}$, biakan murni cendawan Trichoderma sp. (TC) yang diperoleh dari Cipanas Jawa Barat, Trichoderma harzaenum (THA) yang diperoleh dari Biotrop dan cendawan Fusarium sp.

Alat-alat yang digunakan yaitu tabung reaksi, cawan petri, labu Erlenmeyer, pipet, pinset, skalpel, kaca objek dan kaca penutup, jarum ose, lampu spirtus, timbangan, Laminary Air Flow, oven, autoklaf, kamera dan mikroskop.

\section{Metode Penelitian}

\section{Menghitung Persentase Serangan di Lapangan}

Persentase kejadian penyakit yang menyerang bibit gmelina dihitung dengan rumus:

$$
\mathrm{P}=\mathrm{N} X 100 \%
$$

$\mathrm{P}=$ Persentase kejadian penyakit

$\mathrm{n}=$ Jumlah bibit yang terserang penyakit dalam plot pengamatan

$\mathrm{N}=$ Jumlah seluruh bibit dalam plot pengamatan

\section{Pengambilan Sampel Tanaman Terinfeksi Patogen}

Pengambilan sampel tanaman yang terinfeksi patogen berdasarkan pengamatan gejala penyakit, dilakukan secara visual yang meliputi pengamatan penampakan luar bibit gmelina yang terserang penyakit layu, mulai dari gejala awal serangan sampai dengan gejala serangan yang paling parah.

\section{Isolasi Cendawan Patogen}

Isolasi bagian tanaman gmelina yang diduga terinfeksi patogen, kemudian ditumbuhkan pada media PDA, selanjutnya diidentifikasi dan pemurnian.

\section{Peremajaan Isolat Trichoderma sp.}

Isolat Trichoderma sp. yang disimpan pada test tube sebagai koleksi, diremajakan dengan cara menumbuhkan kembali isolat tersebut pada media PDA, kemudian diinkubasi selama 7 hari hingga siap diuji. 


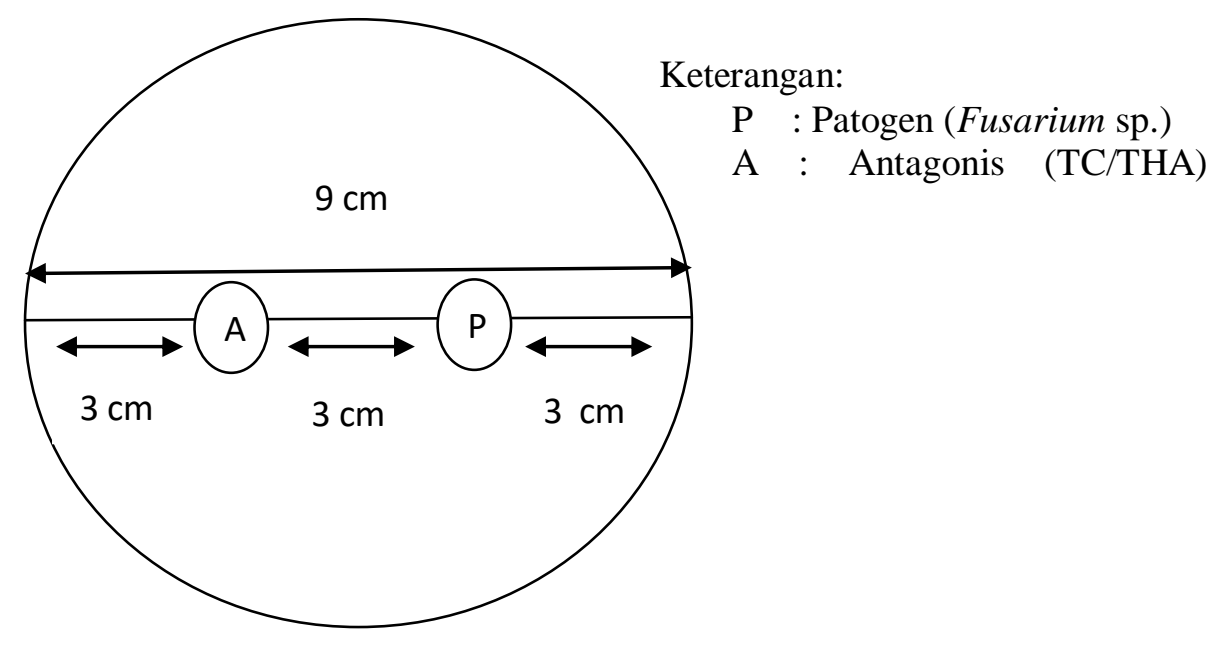

Gambar 1. Peletakan inokulum cendawan

\section{Uji daya Hambat Cendawan Trichoderma sp. Terhadap Fusarium sp.}

Inokulum diambil dari biakan murni PDA dengan ukuran diameter $3 \mathrm{~mm}$, dan diletakkan pada cawan petri yang berisi PDA dengan diameter $9 \mathrm{~cm}$, kemudian dibuat garis tengah dan diberi dua titik. Jarak antara keduanya dari tepi cawan petri yaitu $3 \mathrm{~cm}$, dan jarak antar inokulum cendawan yaitu 3 $\mathrm{cm}$. Cara peletakan inokulum cendawan disajikan pada Gambar 1 (Alfizar et al, 2013).

\section{Persentase Daya Hambat Trichoderma sp. Terhadap Fusarium sp.}

Pengamatan terhadap daya hambat Trichoderma sp. terhadap Fusarium sp. dilakukan pada umur satu hari setelah inokulasi, sampai pertumbuhan Trichoderma sp. dan Fusarium sp. sudah bertemu, dengan cara mengukur pertumbuhan cendawan patogen dan antagonis. Pengamatan dilakukan setiap hari pada waktu yang sama. Daya hambat Trichoderma sp. terhadap Fusarium sp. dihitung dengan menggunakan rumus sebagai berikut (Alfizar et al, 2013):

Keterangan:

$$
\mathrm{P}=\frac{\mathrm{r} 1-\mathrm{r} 2}{\mathrm{r} 1} \times 100 \%
$$

$\mathrm{P}$ : Persentase penghambatan

r1 : Jari-jari koloni patogen yang berlawanan arah dengan cendawan antagonis

r2 : Jari-jari koloni cendawan patogen menuju arah cendawan antagonis

\section{Rancangan Penelitian}

Rancangan penelitian ini menggunakan Rancangan Acak Lengkap (RAL), yaitu menguji potensi daya hambat 2 isolat Trichoderma sp. yang diperoleh dari Cipanas (TC), dengan Trichoderma harzianum yang diperoleh dari BioTrop (THA) terhadap Fusarium sp. yang menyebabkan penyakit layu pada bibit gmelina. Perlakuan dilakukan sebanyak dua perlakuan dan lima ulangan.

\section{Analisis Data}

Hasil pengukuran dianalisis dengan menggunakan SPSS untuk mengetahui pengaruh cendawan TC dan THA terhadap Fusarium sp. Uji lanjutan dengan menggunakan uji lanjut Duncan (Duncan Multiple Range Test /DMRT) pada taraf 5\%.

\section{HASIL DAN PEMBAHASAN}

\section{Identifikasi dan Persentase Serangan Penyakit Layu pada Bibit Gmelina \\ Bibit gmelina di Persemaian Pusat} Litbang Bogor mengalami serangan penyakit layu (Gambar 2). Berdasarkan hasil rekapitulasi data diketahui bahwa persentase serangan penyakit layu pada bibit gmelina tersebut relatif kecil yaitu $4,72 \%$. Hasil identifikasi secara makroskopis maupun mikroskopis, fungi penyebab penyakit lodoh pada kecambah gmelina adalah Fusarium sp. (Deuteromycetes) (Agrios, 2005). 


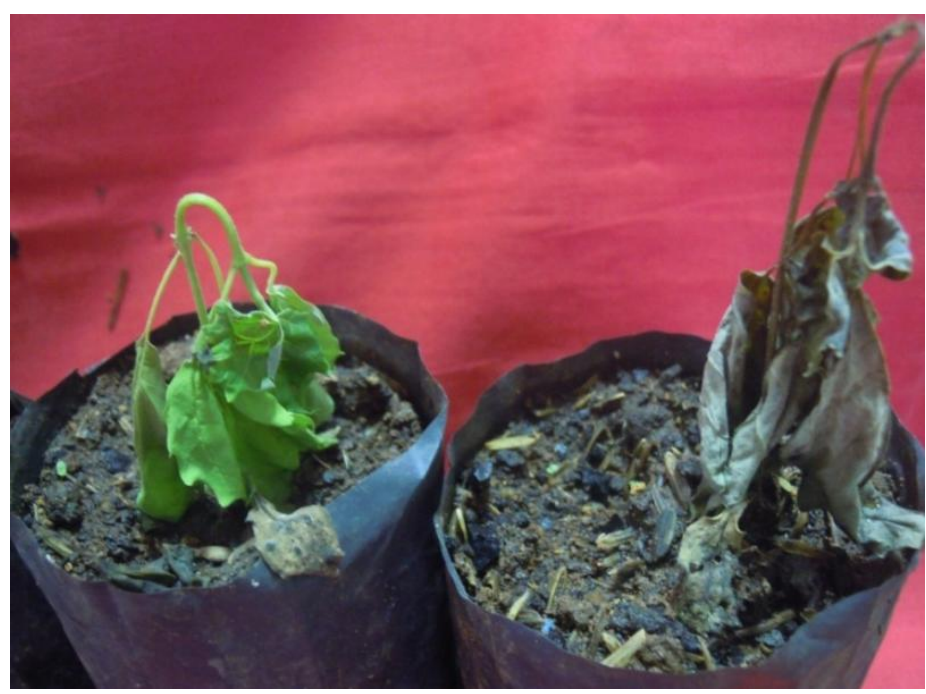

Gambar 2. Penyakit layu yang menyerang bibit gmelina umur 1 bulan

Pada Gambar 2 di atas terdapat bibit yang baru mengalami serangan penyakit layu, ditandai dengan tanaman yang masih berwarna hijau tetapi telah mengalami kelayuan. Serangan lebih lanjut menyebabkan daun tanaman menjadi berwarna cokelat dan mengalami kematian.

Penyakit pada tanaman dapat diketahui dengan mengamati gejala dan tanda yang muncul pada tanaman yang diduga terserang patogen. Hasil pengamatan di persemaian, bibit gmelina menunjukkan gejala layu. Bila bagian akar bibit yang sakit dicabut serta dibersihkan, maka akan terlihat adanya pembusukan pada akar tersebut yang dicirikan dengan menghitamnya bagian luar akar dan agak berair/busuk (Gambar 3). Bagian akar yang membusuk tadi, apabila dipotong secara melintang/membujur, maka terlihat pula perubahan warna pada jaringan yaitu menjadi coklat kehitam-hitaman atau kelabu kehitam-hitaman. Hal ini karena adanya kerusakan pada korteks yang bersifat lokal (Anggraeni \& Mindawati, 2011).

Persentase serangan penyakit layu pada bibit gmelina di persemaian Puslitbang Hutan masih rendah. Hal ini disebabkan kegiatan perawatan dan pemeliharaan pada persemaian sudah baik, sehingga penyakit layu tidak dapat menyebar secara maksimal.

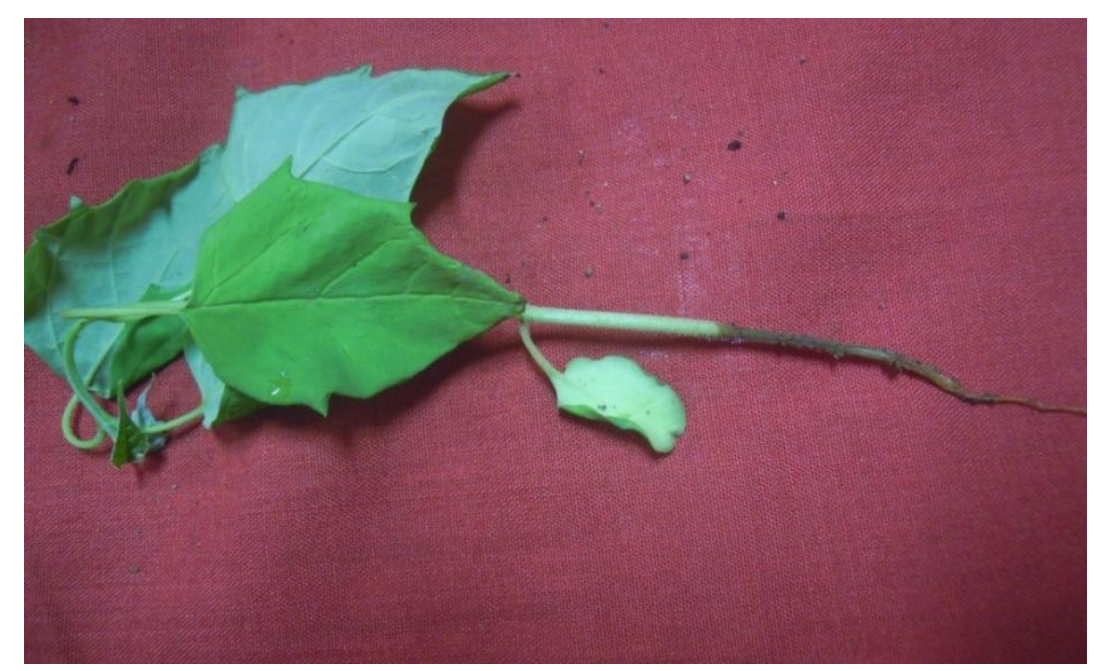

Gambar 3. Gejala serangan pada akar bibit Gmelina 
Hasil identifikasi patogen yang menyerang bibit gmelina yaitu Fusarium sp. (Deuteromycetes), cendawan ini menghasilkan tiga jenis spora yaitu mikrokonidia, makrokonidia dan klamidospora. Mikrokonidia berbentuk oval, bersel satu dan hialin. Mikrospora umumnya terbentuk pada saat patogen berada dalam pembuluh inang. Mikrokonidia merupakan yang paling banyak dibentuk oleh Fusarium sp. dalam berbagai lingkungan. Makrokonidia mempunyai bentuk yang khas yaitu seperti bulan sabit, terdiri dari $3-5$ septa dan berwarna hialin (Gambar 4). Makrokonidia banyak dihasilkan pada permukaan kecambah gmelina yang sakit, sehingga pembuatan preparat dapat dilakukan secara langsung dari jaringan yang sakit. Klamidospora terbentuk pada saat keadaan lingkungan yang tidak menguntungkan (lingkungan ekstrim) terdiri dari 1 - 2 sel berdinding tebal dan dihasilkan pada ujung miselium. Miselium fungi bersepta dan bercabang-cabang dengan warna hialin (Agrios, 2005).

Suharti et al. (1991) mengatakan bahwa cendawan penyebab penyakit rebah kecambah umumnya bersifat parasit fakultatif artinya dapat hidup sebagai saprofit di atas permukaan tanah, dan berubah menjadi parasit apabila ada tanaman inang dan kondisi lingkungan yang baik untuk pertumbuhan.

Fusarium sp. dalam siklus hidupnya mengalami fase patogenesis dan fase saprogenesis. Pada fase patogenesis fungi hidup sebagai parasit dan pada fase saprogenesis fungi bertahan sebagai saprofit pada sisa-sisa tanaman yang kemudian merupakan sumber inokulum untuk menimbulkan penyakit pada kecambah lain. Siklus hidup penyakit yang disebabkan Fusarium sp. sama dengan siklus-siklus hidup penyakit lain yaitu merupakan suatu proses yang terus menerus, dari tahap pertama diikuti oleh tahap berikutnya, tahaptahap tersebut dimulai dengan inokulasi, penetrasi, infeksi, kolonisasi, reproduksi dan diseminasi. Siklus hidup Fusarium sp. di awali dengan masuknya fungi dalam bentuk miselium, makrokonidia, mikrokonidia dan klamidospora melalui luka pada akar, penetrasi langsung maupun melalui celah akar samping kemudian berkembang di dalam jaringan hingga mencapai pembuluh xylem. Cendawan patogen di dalam jaringan inang dapat membentuk enzim pektase, dimana aktivitas enzim pektase tersebut menghasilkan polisakarida dan pektat. Hal ini menyebabkan jaringan xylem tersumbat oleh miselium, polisakarida dan pektat, terjadinya penyumbatan pada sistim pembuluh menyebabkan transportasi air dan hara terganggu, akhirnya kecamabah menjadi layu dan mati. Fusarium sp. dapat menyebabkan perubahan warna pada akar dan nekrosis jaringan (Agrios, 2005). Miselium yang tumbuh terus menembus seluruh jaringan tanaman, mengakibatkan kecambah mati, dan pada permukaan daun terdapat sporodokium yang menghasilkan konidia. Sisa tanaman menjadi substrat untuk bertahan hidup patogen sehingga merupakan sumber inokulum.

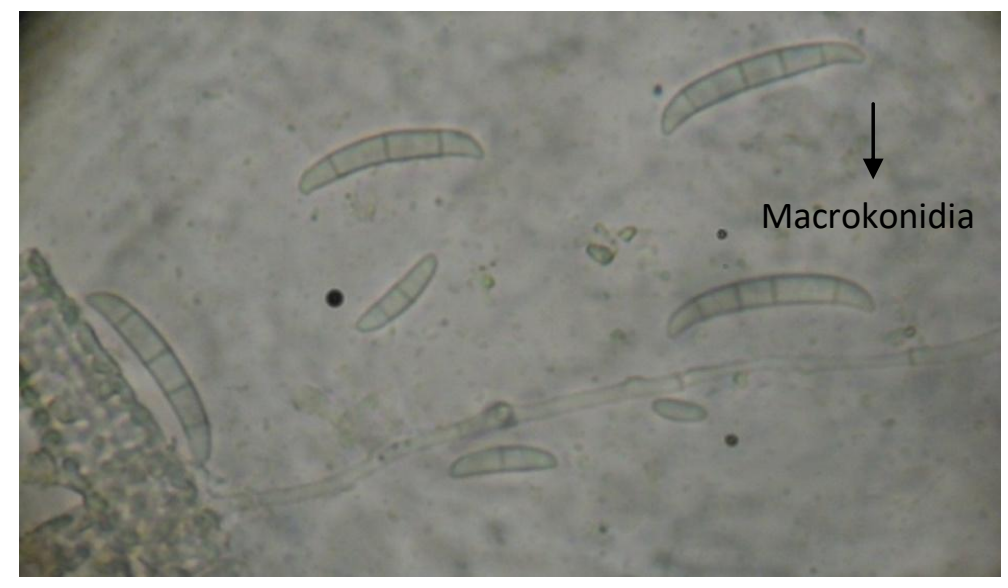

Gambar 4. Makrokonidia Fusarium sp. pada perbesaran 4000x 
Isolat Fusarium sp. yang diperoleh kemudian dilakukan uji Postulat Koch untuk melihat apakah cendawan patogen merupakan penyebab dari penyakit layu pada bibit gmelina tersebut. Pada uji patogenitas atau uji Postulat Koch, kecambah mengalami gejala yang sama dengan gejala pertama yaitu kecambah mengalami rebah dan lodoh. Hal ini terjadi 3 minggu setelah kecambah sehat di inokulasi. Kecambah yang terserang penyakit layu di buat preparat dan diamati di bawah mikroskop, hasilnya menunjukkan fungi patogen yang sama yaitu Fusarium sp. Hal ini sudah sesuai dengan ketentuan Postulat Koch. Uji Postulat Koch adalah untuk pembuktian bahwa fungi Fusarium sp. merupakan penyebab utama penyakit kecambah gmelina.

\section{Uji Antagonis Trichoderma sp. terhadap Fusarium sp. \\ Uji antagonis dua isolat}

Trichoderma sp. dilakukan terhadap Fusarium sp. yang menyebabkan penyakit layu pada gmelina. Rata-rata diameter koloni Trichoderma sp., Fusarium sp. serta daya hambat Trichoderma sp. terhadap Fusarium sp. disajikan pada Gambar 5, 6 dan 7. Berdasarkan hasil penelitian terlihat bahwa terjadi peningkatan rata-rata penghambatan sampai hari ke tiga, pengamatan dihentikan pada hari ketiga karena pertumbuhan Trichoderma sp. dan Fusarium sp. sudah bertemu. Trichoderma harzianum menunjukkan daya hambat yang lebih tinggi daripada Trichoderma sp., dengan daya hambat berturut-turut sebesar 40,31\% dan $33.55 \%$ (Gambar 5). Namun, secara statistik nilai ini tidak berbeda nyata antara kedua isolat Trichoderma sp.

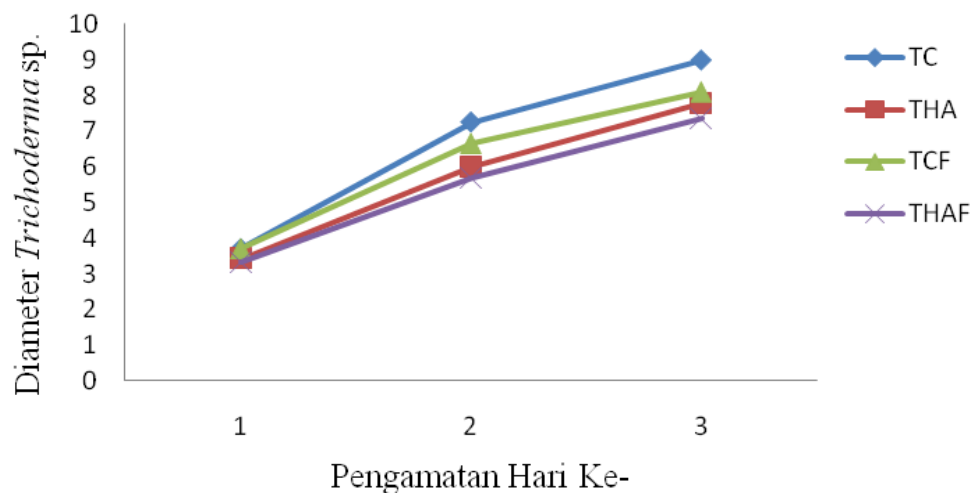

Gambar 5. Pertumbuhan Trichoderma $\mathrm{sp}$. $(\mathrm{TC}=$ Trichoderma sp. pada control, $\mathrm{THA}=$ Trichoderna harzianum pada control, TCF $=$ Pertumbuhan Tricoderma sp. Cipanas pada perlakuan dengan Fusarium sp., THAF = Pertumbuhan Tricoderma harzianum pada perlakuan dengan Fusarium sp.)

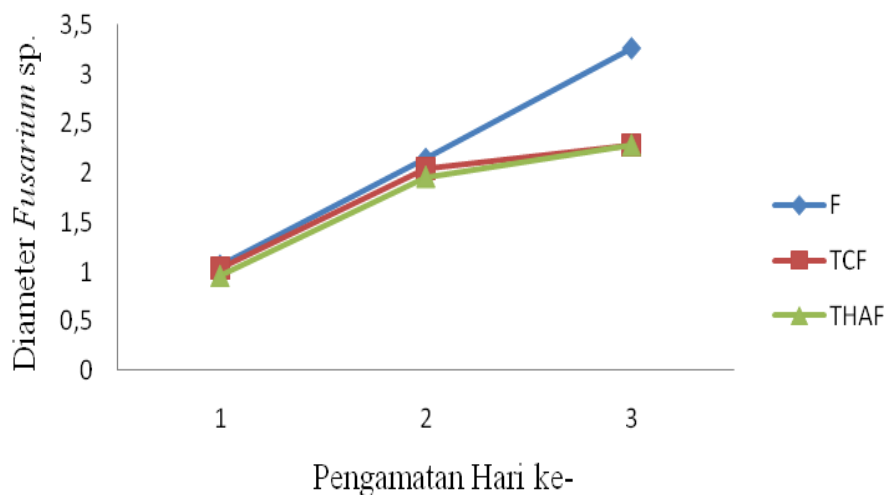

Gambar 6. Pertumbuhan Fusarium sp. (F= Pertumbuhan Fusarium sp. pada control, TCF = Pertumbuhan Fusarium sp. pada perlakuan Trichoderma sp., THAF= Pertumbuhan Fusarium sp. pada perlakuan Trichoderma harzianum) 


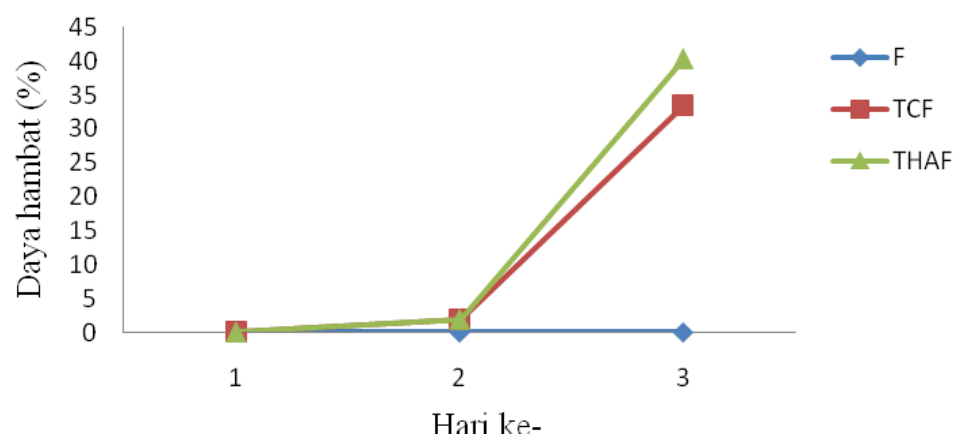

Gambar 7. Rata-rata persentase penghambatan Trichoderma sp. terhadap Fusarium sp. ( $\mathrm{F}=$ Fusarium sp. pada kontrol, TCF = Daya hambat Trichoderma sp. terhadap Fusarium sp., THAF = Daya hambat Trichoderma harzianum terhadap Fusarium sp.)

Dari Gambar 5 dan 6 terlihat bahwa Fusarium sp. tidak dapat tumbuh pada media PDA. Hal ini dikarenakan adanya daya hambat oleh Trichoderma sp. baik THA maupun TC, sedangkan daya hambat Trichoderma sp. terhadap Fusarium sp. disajikan pada Gambar 7.

\section{Mekanisme daya hambat (Antagonis) Trichoderma sp. terhadap Fusarium sp.}

Trichoderma sp. memiliki kemampuan antagonis terhadap cendawan patogen. Pada suatu ekosistem, sangat mudah menemukan Trichoderma sp. di tanah dan akar tanaman yang merupakan mikroorganisme yang menguntungkan, avirulen terhadap tanaman inang dan memiliki kemampuan parasit terhadap cendawan lain (Harman et al., 2004; Alfizar et al., 2013). Trichoderma sp. dikenal sebagai biokontrol antagonis yang bersifat saprofit yang efektif terhadap sejumlah cendawan fitopatogen (Gveroska \& Ziberoski, 2011;Ainy et al., 2015) seperti Fusarium sp. (Hartal, Misnawati, \& Indah, 2010; Ainy et al., 2015), Phytophthora sp. dan Botrytis sp. (Freeman et al., 2003; Ainy et al., 2015). Mekanisme penghambatan cendawan agen hayati terhadap patogen dapat terjadi dengan beberapa mekanisme, yaitu antibiotis yang ditandai dengan terbentuknya zona inhibisi dalam penghambatan pertumbuhannya, kompetisi terhadap substrat ditandai dengan adanya pertumbuhan yang lebih cepat terhadap yang lainnya dan mikoparasitisme yaitu dengan memparasit langsung pada hifa patogennya (Mejía et al., 2008; Lelana, Anggraeni, \& Mindawati, 2015).

Tabel 1. Mekanisme daya hambat cendawan Trichoderma sp. terhadap Fusarium sp.

\begin{tabular}{lll}
\hline $\begin{array}{c}\text { Perlakuan } \\
\text { (Isolat) }\end{array}$ & $\begin{array}{l}\text { Mekanisme } \\
\text { Antagonisme }\end{array}$ & \multicolumn{1}{c}{ Keterangan } \\
\hline THAF & $\begin{array}{l}\text { Kompetisi } \\
\text { ruang dan } \\
\text { mikoparasit }\end{array}$ & $\begin{array}{l}\text { Trichoderma sp. tumbuh } \\
\text { mengungauli patogen pada media } \\
\text { dan juga dapat tumbuh di atas } \\
\text { permukaan koloni patogen }\end{array}$ \\
TCF & $\begin{array}{l}\text { Kompetisi } \\
\text { ruang dan } \\
\text { mikoparasit }\end{array}$ & $\begin{array}{l}\text { Trichoderma sp. mengungguli } \\
\text { patogen pada media dan juga dapat } \\
\text { tumbuh di atas permukaan koloni } \\
\text { patogen }\end{array}$ \\
\end{tabular}


Berdasarkan hasil pengamatan menunjukkan bahwa penghambatan yang terjadi antara isolat cendawan Trichoderma sp. baik THA maupun TC dan Fusarium sp. merupakan penghambatan dengan mekanisme kompetisi ruang, makanan, dan mikoparasit. Mekanisme kompetisi ruang dan makanan yaitu adanya perbedaan luas koloni cendawan pada media, kemampuan untuk berkompetisi agen hayati dengan patogen ditunjukkan oleh besar kecilnya luas koloni agen hayati. Semakin luas pertambahan koloni agen hayati berarti semakin besar kemampuan untuk berkompetisi dengan patogen (Sunarwati \& Yoza, 2010). Mekanisme daya hambat tersebut disajikan pada Tabel 1.

\section{KESIMPULAN}

Cendawan patogen yang menyebabkan penyakit pada bibit gmelina yaitu cendawan Fusarium sp. Serangan penyakit layu Fusarium sp. di persemaian masih rendah yaitu sebesar $4,72 \%$, akan tetapi pengendalian tetap sangat diperlukan sebelum penyakit menyebar dan menyebabkan kerugian yang lebih besar. Hasil uji antagonisme baik THA yang diperoleh dari Biotrop maupun Trichoderma sp. yang diperoleh dari Cipanas, memiliki kemampuan dalam menekan pertumbuhan Fusarium sp. dengan daya hambat masingmasing sebesar $40,31 \%$ dan $33,55 \%$.

\section{DAFTAR PUSTAKA}

Agrios, G. N. (2005). Plant Pathology (5th ed.). USA: Elsevier Academic Press.

Ainy, E. Q., Ratnayani, R., \& Susilawati, L. (2015). Uji Aktivitas Antagonis Trichoderma harzianum 11035 terhadap Colletotrichum capsici TCKR2 dan Colletotrichum acutatum TCk1 Penyebab Antraknosa pada Tanaman Cabai. Seminar Nasional XII Pendidikan Biologi FKIP UNS.

Alfizar, Marlina, dan Susanti, F. (2013). Kemampuan antagonis Trichoderma sp. terhadap beberapa jamur patogen in vitro. Jurnal Floratek, 8(1), 45-51. Retrieved from http://www.jurnal.unsyiah.ac.id/florate $\mathrm{k} /$ article/view/860

Anggraeni, I., \& Mindawati, N. (2011). Serangan Hama dan Penyakit pada Gmelina (Gmelina arbora Roxb.) di Hutan Rakyat. Tekno Hutan Tanaman, 4 (2), 85-92.

Freeman, S., Minz, D., Kolesnik, I., Barbul, O., Zveibil, A., Mayon, M., ... Elad, Y. (2003). Trichoderma Biocontrol of Colletotrichum acutatum and Botrytis cinerea and Survival in Strawberry. Journal of Plant Pathology, 110, 361370.

Gveroska, B., \& Ziberoski, J. (2011). Trichoderma harzianum As A Biocontrol Agent Against Alteraria alternata On Tobaco. Journal Technologies \& Innovations, 7, 67-76.

Harman, A. E., Howell, C. R., Veterbo, A., Chet, I., \& Lorito, M. (2004). Trichoderma Species-OPPORTUNistic, Avirulent Plant Symbionts. Nat. Rev. Microbiol, 2, 34-56.

Hartal, Misnawati, \& Indah, B. (2010). Efektifitas Trichoderma sp. dan Glocladium dp. dalam Pengendalian Layu Fusarium pada Tanaman Krisan. Jurnal Ilmu-Ilmu Pertania, 1, 7-12.

Kosasih, A. S., \& Danu. (2013). Manual Budi Daya Jati Putih (Gmelina Arborea Roxb.). Jakarta: Pusat Penelitian dan Pengembangan Peningkatan Produktivitas HutanBadan Penelitian dan Peengembangan Bekerjasama dengan Direktorat Bina Perbenihan Tanaman Hutan-Direktorat Jenderal Bina Pengelolaan Daerah Aliran Sungai dan Perhutanan Sosial. Kementerian K.

Lelana, N. E., Anggraeni, I., \& Mindawati, N. (2015). Uji Antagonis Asfergilus spp. terhadap Fusarium sp., Penyebab 
Penyakit Rebah Kecambah pada Sengon. Jurnal Penelitian Hutan Tanaman, 12 (1), 23-28.

Mejía, L. C., Rojas, E. I., Maynard, Z., Bael, S. Van, Arnold, A. E., Hebbar, P., ... Herre, E. A. (2008). Endophytic fungi as biocontrol agents of Theobroma cacao pathogens. Biological Control, 46(1), 4-14. https://doi.org/10.1016/j.biocontrol.200 8.01 .012

Mulyana, D., \& Asmarahman, C. (2010). Jenis Kayu Penghasil Rupiah. Jati, Sengon, Mahoni, Meranti, Jati Putih, Kayu Afrika dan Suren. Jakarta: PT. Agro Media Pustaka.

Streets. (1980). Diagnosis Penyakit Tanaman (Terjemahan: Imam Santoso). Tuscon-Arizona. USA: The University of Arizona Press.
Suharti, M., Santoso, E., \& Wibowo, A. (1991). Sebaran Tingkat Serangan dan Teknik Pengendalian Penyakit Bercak Daun pada Eucaliptus spp. Buletin Penelitian Hutan, No. 545.

Sunarwati, D., \& Yoza, R. (2010). Kemampuan Trichoderma Dan Penicillium Dalam Menghambat Pertumbuhan Cendawan Penyebab Penyakit Busuk Akar Durian (Phytophthora palmivora ) Secara In Vitro. Seminar Nasional Program Dan Strategi Pengembangan Buah Nusantara, 286-291.

Tasik, S., \& Widyastuti, S. M. (2015). Mekanisme parasitisme Trichoderma harzianum Terhadap Fusarium oxyporum pada Semai Acacia mangium. Jurnal HPT Tropika, 15(1), 72-80. 